\title{
Family Subjective Well-Being of Health Workers Women During The Covid-19 Pandemic
}

\author{
Euis Sunarti $^{\left.1^{*}\right)}$, Dinda Kamilah ${ }^{2}$, Husniyah Almas ${ }^{3}$, Siti Pitriani ${ }^{4}$ \\ 1,2,3,4 Department of Family and Consumer Sciences, Faculty of Human Ecology, \\ IPB University, Bogor 16680, West Java, Indonesia \\ *) Corresponding author: euissunarti@apps.ipb.ac.id
}

\begin{abstract}
This survey research aims to analyze the factors that influence, as well as test differences in the subjective well-being of the families of women health workers during the Covid-19 pandemic, according to the two types of working time (Stable and shift). This study involved 110 families (47 stable and 63 shift working hours) from Jabodetabek area, which was selected by non-probability random sampling. Data were collected in April 2020. The results showed that women health workers with stable working hours had significantly higher subjective well-being, financial management, and marriage satisfaction, but otherwise had lower husband-wife interactions and work and family problems than women with shift working hours. The results of the main regression model showed that family well-being was influenced positively by coping strategies, marital satisfaction, and husband's education. Meanwhile, the derivative regression model that analyzes the variable components showed that family well-being was influenced positively by a component of marriage satisfaction, a component of family interaction, implementation of family time management, and husband's education; but negatively influenced by family income and husband's age. In general, the family of women health workers during the Covid-19 pandemic was expected to develop various efforts to increase marriage satisfaction and the family's subjective well-being.
\end{abstract}

Keywords: family interaction, family subjective well-being, financial management, marriage satisfaction, women health workers

\begin{abstract}
Abstrak
Penelitian survei ini bertujuan untuk menganalisis faktor-faktor yang memengaruhi, serta menguji perbedaan kesejahteraan subjektif keluarga tenaga kesehatan wanita saat pandemi Covid-19, menurut kedua jenis waktu kerja (Stabil dan shift). Penelitian ini melibatkan 110 keluarga (47 stabil dan 63 jam kerja shift) di wilayah Jabodetabek yang dipilih secara non-probability random sampling. Pengumpulan data dilakukan pada bulan April 2020. Hasil penelitian menunjukkan bahwa tenaga kesehatan wanita dengan jam kerja stabil memiliki kesejahteraan subjektif, manajemen keuangan, dan kepuasan pernikahan yang lebih tinggi secara signifikan, tetapi sebaliknya memiliki interaksi suami-istri yang lebih rendah, serta masalah pekerjaan dan keluarga daripada wanita dengan shift jam kerja. Hasil model regresi utama menunjukkan bahwa kesejahteraan keluarga dipengaruhi secara positif oleh strategi koping, kepuasan perkawinan, dan pendidikan suami. Sedangkan model regresi derivatif yang menganalisis komponen variabel menunjukkan bahwa kesejahteraan keluarga dipengaruhi secara positif oleh komponen kepuasan pernikahan, komponen interaksi keluarga, penerapan manajemen waktu keluarga, dan pendidikan suami; tetapi dipengaruhi secara negatif oleh
\end{abstract}


pendapatan keluarga dan usia suami. Secara umum, keluarga tenaga kesehatan wanita pada masa pandemi Covid-19 diharapkan dapat mengembangkan berbagai upaya untuk meningkatkan kepuasan perkawinan dan kesejahteraan subjektif keluarga.

Kata kunci: interaksi keluarga, kesejahteraan subyektif keluarga, kepuasan pernikahan, manajemen keuangan, tenaga kesehatan wanita

\section{Introduction}

There are increasing numbers of women working nowadays to help the family economy and actualize themselves. BPS data (2019) show an increase of one million women who worked between February 2018 and 2019, bringing it to 52 million. One of the jobs with the most dominant women workforce is health personnel. The latest report from the World Health Organization (WHO) (2019) states that two-thirds of human resources in the global health sector are women.

The Covid-19 pandemic is a case that was first discovered in Wuhan City, China in 2019, and has spread to various countries around the world, including Indonesia. In August 2020, the increase in the number of positive Covid-19 in Indonesia was still high, especially in the Greater Jakarta area, namely Jakarta, Bogor, Depok, Tangerang, and Bekasi (Jabodetabek). Health workers are a job that directly handles Covid-19 patients. The results of research on women health workers in China conducted by Lu, Wang, Lin, and Li (2020), especially women health workers who work in the medical department (respiratory or internal medicine, ER, and ICU) are more likely to feel fear, anxiety, and depression.

The Covid-19 pandemic led to the PSBB (large-scale social restrictions) and the work from home policy, which affected family livelihood activities. In the end, it was thought to affect family well-being. Even though family well-being is the main goal and final goal that a family must achieve (Sunarti, 2013). Prime, Wade, and Browne (2020) are concerned about family well-being during a pandemic because it relates to raising children, maintaining relationships and a sense of security, negotiating family rules or traditions, and facing uncertainty in family life, family upheaval. Family well-being is divided into two aspects, namely, objective and subjective well-being.

According to Sunarti (2001), subjective family well-being measures family needs' satisfaction, especially their basic needs. Subjective well-being consists of physicaleconomic subjective well-being, subjective social well-being, and subjective psychological well-being. Subjective well-being is defined as a good mental state, including all the various evaluations, positive and negative, that people make about their lives and their affective reactions to their experiences (OECD, 2013). Individuals who have married status have higher subjective well-being than those who are not married (Bawono, 2017). The concerns felt by many families during the Covid-19 pandemic could arise due to problems in economic, social, and psychological factors. However, the problem most families feel is economic problems. As Sunarti's research results (2020) reported, as many as 61.1 percent of families with an average income upper middle do not have enough savings to meet family needs in the next six months. This factor is one of the concerns of families during this pandemic. Economic factors are unstable and difficult to predict, may cause new stress on family members, especially parents. Parents, especially wives, who have many burdens, 
namely carrying out their duties as wife/mother at home and working to maintain the family economy, are under quite heavy pressure. This situation occurs due to greater worry for women and a large number of responsibilities that need to be done in their activities, namely both at work and family (Kantamneni, 2020).

Married and working women have a difficult situation in handling family and work duties. Working women have a dual burden conflict, namely conflict between work and family roles, especially during the Covid-19 pandemic. This is due to the large number of responsibilities in work and family that often involve women than men so that working women need better management of both responsibilities (Kantamneni, 2020). Women who already have children, especially children belonging to school age and under, still really need the presence of their parents. The potential for conflict is greater when the source of stress from work or family and the need for emotional support given to children in caring for and guiding child development by working women is difficult to control (Chung, Chan, Lanier, \& Wong, 2020).

The division of roles and responsibilities among family members is an effort that a family with a working husband and wife can do. The division of roles and tasks is increasingly important in the dual-earner family of female health workers with rotating hours (shift), so it is considered important to compare it with those whose working hours are steady (stable). Communication is needed in deciding the division of roles and responsibilities in the family. The relationship between husband and wife, especially in the quality of communication, is needed in crisis times, such as during the Covid-19 pandemic. The source of stress caused by the Covid-19 pandemic situation can reduce communication quality and the sense of togetherness between family members (Prime, Wade, \& Browne, 2020). The quality of an effective husband-wife relationship is necessary to achieve marital satisfaction. The results of Prime, Wade, and Browne's (2020) research show that only a few families experience marriage problems if communication is good between members, even though many families during the Covid-19 pandemic felt a lot of stress. Therefore, this study will look at the influence of husband-wife interaction, time management, marriage satisfaction, family-work problems, family-work conflict, coping strategies, subjective economic pressures, and financial management on women's subjective well-being health workers during the pandemic Covid -19. There is no previous study that has examined this variable in wives who work as health workers during the Corona- 19 pandemics.

Based on the background described in the previous paragraph, this research aims to (1) identify family characteristics and describe the variables studied, namely husband-wife interaction, time management, marriage satisfaction, family work-problems, family workconflict, coping strategies, subjective economic pressure, financial management, and subjective well-being of women health workers during the Covid-19 pandemic, (2) analyze the relationship between various variables studied, (3) analyze differences in research variables according to the working time of women health workers (between those who worked during the day with those who work shift systems ); (4) analyze the influence of family characteristics, husband-wife interactions, time management, marriage satisfaction, family work-problems, family work-conflict, coping strategies, subjective economic pressures, financial management on the subjective well-being of women health workers during the Covid-19 pandemic. 


\section{Methods}

This research is an umbrella study using a cross-sectional study design, a study carried out at a specific time. Data collection was carried out in April 2010 through the distribution of online questionnaires. The consideration of using an online questionnaire is the condition when data collection makes it impossible for researchers to conduct interviews directly in the field due to the Covid-19 pandemic. The study was conducted in Jabodetabek (Jakarta, Bogor, Depok, Tangerang, and Bekasi), which is selected considering the region is detected early occurrence of local transmission and the highest number of Covid 19 in Indonesia (Ministry of Health, 2020).

\section{Participants}

This study's population were intact families, dual-earner family, and the wife who works as a health worker in the Greater Jakarta area. In this study, sampling uses a nonprobability random sampling method involving 110 women health workers, 47 people with stable working hours and 63 people who work shifts. Health workers in this study included general practitioners, specialist doctors, nurses, nutritionists, pharmacists, midwives, physiotherapists, medical techniques, pharmaceutical engineering personnel, and health assistants.

\section{Measurement}

Data were collected using the data primer that is obtained through the help of an online questionnaire include family characteristics, husband and wife interaction, time management, work-family problem, work-family conflict, coping strategies, subjective economic pressure, financial management, marital satisfaction, and subjective well-being of the family. This study used two variables of work-family problems and work-family conflict to distinguish between problems, namely the gap between ideal conditions and reality but not yet causing conflict, with problems that have already caused conflict. The characteristics of families consist of the age of husband and wife, the length of education of the husband and wife, the length of marriage, the length of work of wife, the size of the family, the age of the last child, the husband-wife's income, and the total family income. The following are a description of the research variables:

1) The husband-wife interaction variable uses a questionnaire developed by Chuang (2005). The questionnaire was modified into 17 statements and was measured using a Likert scale of 0 - 3. The Cronbach's alpha value is 0.711 ;

2) The time management questionnaire uses a questionnaire developed using a construct from Nickell and Dorsey (1960). The questionnaire consisted of 10 questions with 3 dimensions, namely planning, implementation, and evaluation, then measured by a Likert scale of 0-3. The Cronbach's alpha value is 0.897;

3) Marriage satisfaction consists of 10 dimensions, namely partner personality problems, equality of roles, communication, conflict resolution, financial management, joint activities, sexual relations, children and marriage, family and friends, and religious orientation. This instrument modifies the ENRICH (Evaluation and Nurturing Relationship Issues, Communication, and Happiness) measurement tool Marital Satisfaction (EMS) from Fowers and Olson (1993). The initial number of instruments 
consisted of 11 question items with a Likert scale but changed to a semantic scale of 17 so that the data could be closer to the ratio. The Cronbach's alpha value is 0.940 ;

4) Work-family problems variable were elaborated using instruments developed by Sultana (2013). There are 6 questions using ratings of 0 (no) and 1 (yes). The result of the reliability value of Cronbach's Alpha on this instrument is 0.728 ;

5) The work-family conflict variable used an instrument developed by Netemeyer, Boles, and McMurrian (1996). The scale used in this measurement is the Likert scale with ratings starting from 0 (disagree), 1 (disagree), 2 (agree), 3 (strongly agree). The Cronbach's Alpha value on this instrument is 0.887 ;

6) The coping strategy variable uses The Dual Employed Coping Scales (DECS) developed by Skinner and McCubbin (1982). The DECS instrument uses a Likert measurement scale with ratings starting from 0 (disagree), 1 (disagree), 2 (agree), 3 (strongly agree). The Cronbach's alpha value on this instrument is 0.767 ;

7) The subjective economic pressure variable is referenced from Hilton and Devall (1997), which consists of 12 statements. The questionnaire uses a Likert scale 1-5 with the explanation of the answer " $1=$ never, $2=$ rarely, $3=$ sometimes, $4=$ often, and $5=$ always". The Cronbach's alpha value on this questionnaire was 0.769 ;

8) This financial management variable, which includes the planning, implementation, and evaluation stages, are referred to and modified from Firdaus and Sunarti (2009). The total items that measure the financial management variable are seven statements. The questionnaire uses a Likert scale rating of 0-3 with the explanation of the answer " $0=$ never, $1=$ sometimes, $2=$ often and $3=$ always". The Cronbach's alpha value on this questionnaire was 0.786 ;

9) The family subjective well-being variable is referred to and modified by Sunarti (2001) which consists of three dimensions, namely physical-economic, social and psychological. The total items that measure the financial management variable are seventeen statements. The assessment uses a semantic scale ranging from 1 (low) to 7 (high). The Cronbach's alpha value on this questionnaire was 0.763 .

\section{Analysis}

The data obtained by researchers were then processed through the editing, coding, entrying, scoring, entering, and cleaning processes. Data processing and analysis were carried out using the Microsoft Excel 2019 application, Statistical Package for Social Sciences (SPPS) 25.0 for windows. The statistical analysis used is descriptive analysis and inferential analysis (correlation test, independent sample t-test, and multiple linear regression). The two statistical analyzes are used to see the distribution of family characteristics, relationships, differences, and influences among the nine research variables studied.

\section{Findings}

\section{Family Characteristics}

The results showed that the ages of husbands and wives were at the age of 32 to 35 years. The average length of education for women health workers with a shift system and 
stable working hours is 15.56 years (shift system) and 15.60 years (stable working hours), or the equivalent of a D3 / D4 / S1 graduate. The average length of work for women health workers in the hospital or their workplace is longer for women health workers with stable working hours, that is, they have worked for 11.64 years. As well as the average length of marriage, women health professionals who work with stable than the system working hours shift, is 10.57 years.

Table 1. Distribution of Family Characteristics Data Based on The Working Time System (Shift and Stable)

\begin{tabular}{|c|c|c|c|c|c|c|}
\hline \multirow{3}{*}{$\begin{array}{l}\text { Family Characteristics } \\
\text { (unit) }\end{array}$} & \multicolumn{4}{|c|}{ Working time system } & \multirow{2}{*}{\multicolumn{2}{|c|}{ Total }} \\
\hline & \multicolumn{2}{|c|}{ Shift } & \multicolumn{2}{|c|}{ Stable } & & \\
\hline & Min-Max & Mean & Min-Max & Mean & Min-Max & Mean \\
\hline Husband's age (years) & $23-52$ & 32 & $25-62$ & 39 & $23-62$ & 35 \\
\hline Wife's age (years) & $23-50$ & 30 & $22-55$ & 35 & $22-55$ & 32 \\
\hline $\begin{array}{l}\text { Length of husband's } \\
\text { education (years) }\end{array}$ & $12-24$ & 15.14 & $9-21$ & 15.62 & $9-24$ & 15.35 \\
\hline $\begin{array}{l}\text { Length of wife's } \\
\text { education (years) }\end{array}$ & $12-18$ & 15.56 & $12-19$ & 15.60 & $12-19$ & 15.57 \\
\hline $\begin{array}{l}\text { Length of work for wife } \\
\text { (years) }\end{array}$ & $1-30$ & 7.02 & $1-36$ & 11.64 & $1-36$ & 8.99 \\
\hline $\begin{array}{l}\text { Length of marriage } \\
\text { (years) }\end{array}$ & $1-23$ & 5.57 & $1-30$ & 10.57 & $1-30$ & 7.71 \\
\hline Family size (person) & $2-5$ & 3 & $2-7$ & 4 & $2-7$ & 3 \\
\hline Last child age (years) & $0-17$ & 3 & $0-26$ & 6 & $0-26$ & 4 \\
\hline $\begin{array}{l}\text { Total income (thousand } \\
\text { rupiah) }\end{array}$ & $\begin{array}{c}4300- \\
1000000\end{array}$ & 27056 & $5500-65000$ & 15414 & $\begin{array}{c}4300- \\
1000000\end{array}$ & 22082 \\
\hline $\begin{array}{l}\text { Growth domestic } \\
\text { product/capita (thousand } \\
\text { rupiah) }\end{array}$ & $\begin{array}{c}1075- \\
333333\end{array}$ & 9291 & $1142-16250$ & 4425 & $\begin{array}{c}1075- \\
333333\end{array}$ & 7212 \\
\hline
\end{tabular}

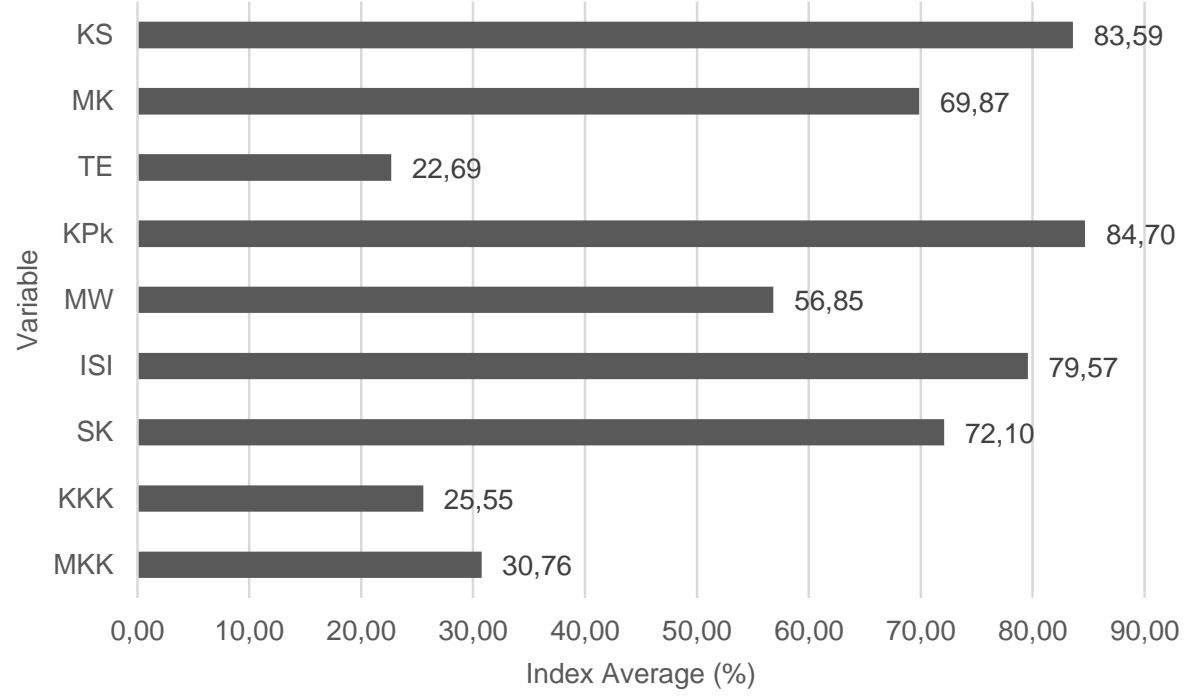

Figure 1. The Average of Variable Index on Women Health Workers. Notes: KPk= Marriage Satisfaction; MW= Time Management; ISI= Husband-Wife Interaction; KS= Subjective Family Well-being; MK= Financial Management; $\mathrm{TE}=$ Economic Pressure; SK= Coping Strategy; KKK= Work-Family Conflict; MKK= Work-Family Problems 
Data on Table 1 shows the families are in the small family category ( $\leq 4$ people) by the average number of family members in the sample with the system shift as many as 3 people and samples with stable working hours as many as four people. The average age of the last child in the sample with stable working hours is six years older, while the average age of the last child using the shift system is 3 years. The total family income for women health workers on the shift system ranges from Rp4,300,000 to Rp1,000,000,000, and for

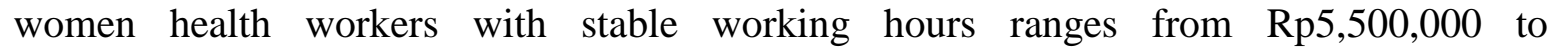
Rp65,000,000. Average family samples include the non-poor, with a per capita income above Rp440,538 (Rp7,212,017). The distribution of samples based on occupation was mostly in the type of work of health care workers, namely 46 samples (41.80\%). Nurse health workers mostly work on shift work systems, namely 28 samples, while in the stable time system, there are 18 samples. The study's least occupational types are specialists $(2.70 \%)$ and physiotherapists $(2.70 \%)$.

\section{Differences in Subjective Economic Pressure, Financial Management and Subjective Well-being of Women Health Workers in Stable Shift and Working Hours Systems}

The independent sample t-test results of different tests on subjective economic pressure ( $p$-value $>0.05)$ and financial management $(p$-value $>0.05)$ (Table 2$)$ indicate that the shift system has no significant difference with stable working hours. Meanwhile, the independent sample t-test results on subjective well-being show that the shift system has a significant difference with stable working hours in the physical-economic dimension with p-value $<0.10$. These results indicate that women health workers during stable working hours have a higher physical-economic subjective well-being than women health workers on the shift system.

Table 2. Different Test Results Independent Sample T-Test Subjective Economic Pressure, Financial Management, and Subjective Well-Being Based on Working Time Systems (Shift and Stable)

\begin{tabular}{lcccc}
\hline \multirow{2}{*}{ Variable } & \multirow{2}{*}{ Mean Difference } & \multicolumn{2}{c}{ Mean } & \multicolumn{2}{c}{$\begin{array}{c}\text { Sig. (2- } \\
\text { tailed) }\end{array}$} \\
\cline { 3 - 5 } Subjective economic pressure & & Shift & Stable & 0.771 \\
\hline Financial management & 0.996 & 23.115 & 23.119 & 0.670 \\
\hline Planning & 1.878 & 70.673 & 68.794 & 0.910 \\
Implementing & 0.600 & 64.903 & 64.303 & 0.348 \\
Evaluating & 3.888 & 80.247 & 76.359 & 0.961 \\
\hline Subjective well-being & -0.315 & 59.259 & 59.574 & 0.271 \\
\hline Physics-economy & $-2,754$ & 82.415 & 85.169 & $\mathbf{0 . 0 5 7 *}$ \\
Social & -5.088 & 81.614 & 86.702 & 0.431 \\
Psychology & -2.221 & 78.748 & 80.969 & 0.332 \\
\hline$N$
\end{tabular}

Note: $*$ significant $\mathrm{p}<0.10$ 
Differences in Husband and Wife Interaction, Time Management, and Marriage Satisfaction in Shift and Stable Systems

The independent sample t-test in Table 3 show that there is no significant difference in time management between women health workers who work with the shift system and normal working hours. There is a significant difference in family interaction $(p<0.10)$ and marital satisfaction $(\mathrm{p}<0.05)$ between women health workers who work with a shift system and normal working hours. The directional dimension in the husband-wife interaction of the health worker family with the shift system is higher than the stable working hours, while the dimensions of financial management and family religious orientation of health workers with stable working hours are higher than the shift work system.

Table 3. Different Test Results Independent Sample T-Test Husband-Wife Interaction, Time Management, and Marriage Satisfaction Based on the Working Time System (Shift and Stable)

\begin{tabular}{lcccc}
\hline \multirow{2}{*}{ Variable } & \multirow{2}{*}{ Mean difference } & \multicolumn{2}{c}{ Mean } & $\begin{array}{c}\text { Sig. (2- } \\
\text { tailed) }\end{array}$ \\
\cline { 3 - 4 } & & Shift & Stable & 0.667 \\
\hline Husband-Wife Interaction & 0.754 & 79.894 & 79.140 & 0.210 \\
\hline Affection & 5.601 & 80.423 & 74.823 & $\mathbf{0 . 0 9 4 *}$ \\
Instruction & 7.329 & 72.222 & 64.894 & 0.988 \\
Mastery & 0.025 & 88.677 & 88.652 & 0.256 \\
Quarrel & -2.637 & 87.434 & 90.071 & 0.511 \\
Obedience & -2.477 & 48.942 & 51.418 & 0.763 \\
Appreciate & 1.165 & 80.952 & 79.787 & 0.849 \\
\hline Time Management & -0.797 & 56.508 & 57.305 & 0.389 \\
\hline Planning & 4.323 & 57.848 & 62.175 & 0.124 \\
Implementing & 5.572 & 69.048 & 63.475 & 0.530 \\
Evaluating & 3.422 & 39.947 & 36.525 & 0.288 \\
\hline Marriage Satisfaction & -2.854 & 83.478 & 86.331 & 0.749 \\
\hline Partner personality problems & -1.013 & 82.143 & 83.156 & 0.740 \\
Equality of roles & -1.227 & 80.688 & 81.915 & 0.433 \\
Communication & -2.826 & 81.217 & 84.043 & 0.478 \\
Conflict resolution & -2.471 & 81.217 & 83.688 & $\mathbf{0 . 0 8 2 *}$ \\
Financial management & -6.349 & 76.984 & 83.333 & 0.387 \\
Group activities & -2.600 & 88.889 & 91.489 & 0.659 \\
Sexual relations & -1.351 & 87.302 & 88.652 & 0.235 \\
Children and marriage & -3.563 & 86.508 & 90.071 & 0.604 \\
Family and friends & -2.043 & 84.127 & 86.170 & $\mathbf{0 . 0 2 0 * *}$ \\
Religious orientation & -6.935 & 87.037 & 93.972 &
\end{tabular}

Note: $*=$ significant $\mathrm{p}<0.10, * *=$ significant $\mathrm{p}<0.05$

\section{Differences between Work-Family Problems, Work-Family Conflict, and Coping Strategies between Shift and Stable Hours of Work for Women Health Workers}

The independent sample t-test difference on family work problems shows that there are significant differences (Table 4). Overall, the results showed that the work-family problems among women health workers with a stable shift system and working hours had a significant difference. Women health workers with the system shift and stable working hours have different results, especially on a problem early did not have time to come and get the family event of the husband's complaint due to lack of time with him. Suppose the 
comparison between women's health personnel who work with the system shifts and working hours is stable. In that case, it appears (Table 6) that women health workers who work with the system shifts have the problem more than women health workers who work with stable working hours.

Table 4. Different Test Results Indicators of Work-Family Problems Based on the Working Time System (Shift and Stable)

\begin{tabular}{lcccc}
\hline \multirow{2}{*}{ Indicator } & $\begin{array}{c}\text { Mean } \\
\text { difference }\end{array}$ & Shift & Stable & $\begin{array}{c}\text { Sig (2- } \\
\text { tailed) }\end{array}$ \\
\cline { 3 - 5 } & 5.133 & 34.920 & 29.790 & 0.574 \\
Not having enough time to rest or have fun & 15.738 & 41.270 & 25.530 & $\mathbf{0 . 0 8 2}^{*}$ \\
Not having time to come to family events & 15.299 & 23.810 & 8.510 & $\mathbf{0 . 0 2 6}^{* *}$ \\
Getting complaints from her husband for lack of & 12.563 & 38.100 & 25.530 & 0.161 \\
time with her & 8.274 & 44.440 & 36.170 & 0.387 \\
Very tired due to long working hours & 8.882 & 30.160 & 36.170 & 0.292 \\
Can not dot he domestics role properly & 10.982 & 35.450 & 24.468 & $\mathbf{0 . 0 5 5}^{*}$ \\
Facing problems when the child is sick & & & &
\end{tabular}

Table 5 shows the results of different tests between the dimensions of coping strategies and work-family conflict among women health workers (stable and shift working hours). The results show no significant difference in any dimensions of coping strategies between women health workers with a shift work system and stable working hours. The test results for different dimensions of work-family conflict show that women health workers with the shift system experience more work conflicts that affect the family than women health workers who have stable working hours.

Table 5. Test Results on Different Dimensions of Coping Strategy and Work-Family Conflict Based on the Working Time System (Shift and Stable)

\begin{tabular}{|c|c|c|c|c|}
\hline \multirow{2}{*}{ Variable } & \multirow{2}{*}{$\begin{array}{c}\text { Mean } \\
\text { difference }\end{array}$} & \multicolumn{2}{|c|}{ Mean } & \multirow{2}{*}{$\begin{array}{l}\text { Sig (2- } \\
\text { tailed) }\end{array}$} \\
\hline & & Shift & Stable & \\
\hline Coping strategy & -2.399 & 71.075 & 73.475 & 0.246 \\
\hline Maintaining family system & -1.987 & 56.878 & 58.865 & 0.592 \\
\hline Procurement of support & -3.552 & 67.725 & 71.277 & 0.299 \\
\hline Modifying role and standards & -1.554 & 69.841 & 71.395 & 0.510 \\
\hline Maintaining perspective and reducing tension & -3.118 & 79.577 & 82.695 & 0.249 \\
\hline Work-family conflict & 3.491 & 27.037 & 23.546 & 0.328 \\
\hline Work to family conflict & 7.574 & 36.085 & 28.511 & $0.082 *$ \\
\hline Family to work conflict & -0.592 & 17.989 & 18.582 & 0.875 \\
\hline
\end{tabular}


Table 6. Results for Differences Test Between Variables Based on the Working Time System (Shift and Stable)

\begin{tabular}{lcccc}
\hline \multirow{2}{*}{ Variable } & \multirow{2}{*}{ Mean difference } & \multicolumn{2}{c}{ Mean } & \multirow{2}{*}{ Sig (2-tailed) } \\
\cline { 3 - 4 } & & Shift & Stable & N $^{*}$ \\
Work-family problem & 10.982 & 35.450 & 24.468 & $\mathbf{0 . 0 5 5}^{*}$ \\
Coping strategy & -2.399 & 71.075 & 73.475 & 0.246 \\
Work-family conflict & 3.491 & 27.037 & 23.546 & 0.328 \\
Husband-wife interactions & 0.754 & 79.894 & 79.140 & 0.667 \\
Time management & -0.797 & 56.508 & 57.305 & 0.849 \\
Marriage satisfaction & -2.854 & 83.478 & 86.331 & 0.288 \\
Economy pressure & 0.996 & 23.115 & 22.119 & 0.771 \\
Finansial management & 1.878 & 70.673 & 68.794 & 0.670 \\
Subjective family well-being & -2.754 & 82.415 & 85.169 & 0.271 \\
\hline
\end{tabular}

Note: *) significant at $\mathrm{p}<0.1$

\section{The Effect between Variables on Subjective Well-being}

The results of the regression test (Table 7) prove that there is a significant positive effect on the characteristics of the husband's length of education $(\beta=0.822)$, coping strategy variables $(\beta=0.138)$, and marital satisfaction $(\beta=0.703)$ on subjective well-being. This means that every one-unit increase in the coping strategy will increase subjective well-being by 0.138 , and each increase in one unit of marriage satisfaction will increase subjective wellbeing by 0.703 . This first regression model has an effect of 65.9 percent, and the rest (34.1\%) is influenced by other variables not examined in the study.

The results in the second model show that the characteristics of the husband's length of education $(\beta=0.839)$, respect dimensions $(\beta=0.103)$ in husband-wife interactions, communication dimensions $(\beta=0.265)$, sexual relations $(\beta=0.140)$, family and friends $(\beta=$ 0.259) of the variable marriage satisfaction has a significant positive effect on subjective well-being. While the results on the characteristics of the husband's age $(\beta=-0.310)$, total income, and implementation dimensions $(\beta=-0.142)$ in time management have a significant negative effect on subjective well-being. The value of Adjusted $R$ Square shows that the second model can explain 74.2 percent of the effect of marriage satisfaction on subjective well-being variables, the rest $(25.8 \%)$ is influenced by other variables not examined.

Table 7. Distribution Regression Coefficients of Family Characteristics, Coping Strategies, Husband-Wife Interaction, Marriage Satisfaction, and Financial Management on Subjective Well-being

\begin{tabular}{llccc}
\hline & Variable & Unstandardized & Standardized & Sig. \\
$(\boldsymbol{\beta})$ & 11.907 & & 0.305 \\
& Regression constant & -0.150 & -0.102 & 0.338 \\
\multirow{3}{*}{ Model 1 } & Husband's age & 0.822 & 0.145 & $\mathbf{0 . 0 3 4 *}$ \\
& Length of education of husband & -0.540 & -0.065 & 0.317 \\
& Length of education of wife & 0.197 & 0.123 & 0.238 \\
& Length of work for wife & $-1.184 \mathrm{E}-8$ & -0.087 & 0.167 \\
& Total family income & 0.138 & 0.109 & $\mathbf{0 . 0 7 2 *}$ \\
& Coping strategy & 0.012 & 0.021 & 0.796 \\
& Financial management & -0.025 & -0.010 & 0.889
\end{tabular}


Sunarti, Kamilah, Almas, \& Pitriani / Journal of Family Sciences, 2020, Vol. 05, No. 02

\begin{tabular}{|c|c|c|c|c|}
\hline & Variable & $\begin{array}{c}\text { Unstandardized } \\
(\beta)\end{array}$ & $\begin{array}{c}\text { Standardized } \\
(\beta)\end{array}$ & Sig. \\
\hline & Time management & 0.032 & 0.030 & 0.709 \\
\hline & Marriage satisfaction & 0.703 & 0.768 & $0.000 * *$ \\
\hline & $\mathrm{F}$ & & 22.056 & \\
\hline & Adj. R Square & & 0.659 & \\
\hline & Sig. & & 0.000 & \\
\hline & Regression constant & 18.067 & & 0.175 \\
\hline & Husband's age & -0.310 & -0.210 & $0.054^{*}$ \\
\hline & Length of education of husband & 0.839 & 0.148 & $0.026^{* *}$ \\
\hline & Length of education of wife & -0.720 & -0.087 & 0.150 \\
\hline & Length of work for wife & 0.175 & 0.110 & 0.274 \\
\hline & Total family income & $-1.448 \mathrm{E}-8$ & -0.106 & $0.072^{*}$ \\
\hline & Coping strategy & & & \\
\hline & Maintaining family system & 0.017 & 0.026 & 0.668 \\
\hline & Procurement of support & 0.038 & 0.052 & 0.472 \\
\hline & Modifying role and standards & 0.087 & 0.082 & 0.284 \\
\hline & $\begin{array}{l}\text { Maintaining perspective and reducing } \\
\text { tension }\end{array}$ & 0.040 & 0.043 & 0.524 \\
\hline & Financial management & & & \\
\hline & Planning & 0.007 & 0.016 & 0.871 \\
\hline & Implementing & -0.024 & -0.040 & 0.643 \\
\hline & Evaluating & 0.003 & 0.007 & 0.932 \\
\hline & Husband-Wife Interaction & & & \\
\hline & Affection & -0.029 & -0.052 & 0.544 \\
\hline \multirow[t]{23}{*}{ Model 2} & Instruction & 0.012 & 0.021 & 0.744 \\
\hline & Mastery & 0.020 & 0.013 & 0.822 \\
\hline & Quarrel & -0.029 & -0.027 & 0.677 \\
\hline & Obedience & 0.006 & 0.009 & 0.891 \\
\hline & Appreciate & 0.103 & 0.159 & $0.040^{* *}$ \\
\hline & Time Management & & & \\
\hline & Planning & 0.051 & 0.103 & 0.254 \\
\hline & Implementing & -0.142 & -0.206 & $0.014^{* *}$ \\
\hline & Evaluating & 0.047 & 0.102 & 0.132 \\
\hline & Marriage Satisfaction & & & \\
\hline & Partner personality problems & -0.091 & -0.115 & 0.331 \\
\hline & Equality of roles & -0.019 & -0.027 & 0.814 \\
\hline & Communication & 0.265 & 0.381 & $\mathbf{0 . 0 0 2}^{* *}$ \\
\hline & Conflict resolution & -0.101 & -0.141 & 0.215 \\
\hline & Financial management & 0.101 & 0.148 & 0.141 \\
\hline & Group activities & 0.087 & 0.104 & 0.209 \\
\hline & Sexual relations & 0.140 & 0.171 & $0.075^{*}$ \\
\hline & Children and marriage & -0.020 & -0.024 & 0.780 \\
\hline & Family and friends & 0.259 & 0.408 & $0.000^{* * * *}$ \\
\hline & Religious orientation & 0.076 & 0.092 & 0.229 \\
\hline & $\mathrm{F}$ & & 11.110 & \\
\hline & Adj. R Square & & 0.742 & \\
\hline & Sig. & & 0.000 & \\
\hline
\end{tabular}

Note: $* * *)$ significant at $\mathrm{p}<0.01, * *)$ significant at $\mathrm{p}<0.05, *)$ significant at $\mathrm{p}<0.1$ 


\section{Discussion}

The regression test results on both regression models indicate that marital satisfaction has a consistently significant positive effect on subjective well-being. Dimensions of communication, sexual relations, family, and friends also positively influence subjective well-being. According to Diener and Ryan (2009), husband and wife are assumed to have social satisfaction when they have closeness with other people, have supportive friends and family, and be satisfied with their entire lives. This means that the higher the satisfaction of the marriage will increase the subjective well-being of the family. In line with Anindya and Soetjiningsih (2017) research, the factor that affects subjective well-being is marriage satisfaction because marriage satisfaction contains subjective assessments of several things about perceptions in marriage, such as happiness, satisfaction, and pleasant experiences with a partner. Research Carr et al. (2014) stated that the wife's marital happiness increases marital satisfaction. Marital quality also influenced parenting environment quality in dual-earner family (Rizkillah, Sunarti, \& Herawati, 2015).

Subjective well-being in this study is influenced by family coping strategy factors, but it is not consistent in all models. The efforts made by the family to overcome and balance the role of the family and a good job will improve the subjective well-being of the family. Based on research conducted by Ryu, Yang, and Choi (2020), the efforts made to minimize problems are using a method that focuses on problem-solving that can improve subjective well-being. The results showed that the interaction between husband and wife who respect each other would also affect subjective well-being. These results are in line with Suwartini and Casmini's (2019) research, which shows that family harmony can be achieved when husband and wife are able to overcome misunderstandings that occur with an attitude of mutual understanding (understanding) with each other. The realized harmony can lead the family to high subjective well-being when the husband and wife experience more feelings of pleasure, happiness, and satisfaction. This shows that husband and wife with good subjective well-being are characterized by the dominance of positive aspects and low negative aspects of themselves.

The length of the husband's education has a positive correlation and influence on subjective well-being. The data of this research indicate that the husband's length of education is 15.4 years. This means that the husband's high education level can improve the family of women health workers' subjective well-being. These results are in line with Aceleanus's research (2012) that education offers some benefits, such as improving living standards and quality of life. A high husband's education will provide ample opportunities to increase the capacity of skills and insights to increase better job opportunities and contribute to the fulfillment of well-being objectively so that it will increase subjective well-being. The average age of the husband in young adulthood, which is 34.7 years, has a negative effect on subjective well-being, meaning that the husband's young age will further improve subjective well-being. The results of research also support this by Elmanora, Muflikhati, and Alfiasari (2012) that the younger father's age will improve family well-being than the older father's age.

The higher the total family income, the lower the subjective well-being of the family. According to Kahneman and Deaton (2010), families at high-income levels do not necessarily get happy lives and improve subjective well-being in the long run. Low-income 
families may improve the subjective well-being of their families. This is supported by research data, which shows that women's subjective well-being with stable working hours has a higher subjective physical-economic well-being than women health workers with a shift system. According to the data, the family income of women health workers during stable working hours ranges from Rp.5,500,000 to Rp.65,000,000 lower than women health workers on the shift system, namely Rp.4,300,000-1,000,000,000. Therefore, the subjective physical-economic well-being during stable working hours is higher on average than the shift system.

The correlation test results show that the husband's age, wife's age, length of work, and length of marriage are negatively related to the variables of work-family problems and family-work conflicts. The work-family conflict between the family and the working wife will decrease as the husband and wife's age increases. As well as the age of marriage, the length of the marriage could low of work-family conflict experienced (Yang, Chen, Choi, \& Zou, 2000). A significant positive relationship occurred between the wife's length of education and financial management. This shows that the higher the wife's education, the better the wife's ability to carry out family financial management (Firdaus \& Sunarti, 2009).

The work-family problem variable has a significant positive relationship with family work conflicts and subjective economic pressure. Based on the results of research by Alteza and Hidayati (2008) and Dwiyanti and Rahardjo (2016), problems with husbands, economic burdens, responsibility for managing the household, limited time for family, busy work schedules or long working hours have a relationship with work conflicts that affect family and family conflicts affect work. Stress raising or caring for children, especially those with children aged at below 17 years needs a lot of time, energy, and finance that will lead to economic pressures in household expenditure (Yan \& Zhou, 2016).

Work-family problems and work-family conflicts have a significant negative relationship with husband-wife interactions, marital satisfaction, and subjective wellbeing. Following the research by Meliani, Sunarti, and Krisnatuti (2014), high work conflicts that disrupt the family and family conflicts that interfere with work can reduce marital satisfaction. The interaction between family members needs to be taken into account in workfamily conflicts because when individuals experience work-family conflicts, it can potentially decrease marital satisfaction (Minnotte, Minnotte, \& Bonstrom, 2015). Workfamily conflict also has negative effects on wives' job satisfaction (Sunarti, Rizkillah \& Muktiyah, 2020). Subjective well-being increases if the demands from work and family and activities between work and family that are contradicting each other are slightly felt by working women (Achour, Nor, \& Yusoff, 2015). Couples who both work with high pressure from work can reduce marriage satisfaction (Sun, McHale, Crouter, \& Jones, 2017).

There is a significant positive relationship in husband-wife interaction and time management on marriage satisfaction, financial management, and subjective wellbeing. This shows that the higher the family interaction, the better financial management, marriage satisfaction, and subjective well-being. Theoretical and empirical studies prove that interaction patterns between partners have an important role in marriage satisfaction (Canel, 2013). The correlation test results show that the better the time management, the higher the marriage satisfaction. This is in line with Amfani (2018), the ability to manage time effectively allows working wives to make time for the family, which increases the potential for marriage satisfaction. 
Coping strategies have a significant positive relationship with time management, marriage satisfaction, financial management, and subjective well-being. This shows that the better the coping strategy is implemented, it will optimize time management and financial management as well as increase marriage satisfaction and subjective well-being. Strategies used in families with husband and wife work can be effective if they use time efficiently, such as delegating, sharing roles, doing multiple tasks to generate 'more' time - family time (Forsberg, 2009). The adjustment of the role together with the husband to the working wife is a determining factor for marriage satisfaction, and this is because the working wife feels that her marriage is going according to her expectations. Financial status is a factor related to a person's stress, which can impact the financial crisis. The stress experienced by a person or the family with ignorance in financial management has the potential for the financial crisis (Steen \& MacKenzie, 2013).

The directional dimension on the husband-wife interaction of women health workers with the shift work system is higher than the stable working hours, while the dimensions of financial management and religious orientation on the marriage satisfaction of women health workers with stable working hours are higher than the shift work system. This relates to partners directing each other in making decisions and reminding each other of their duties. According to Adnan (in Marchelia, 2014), the shift work system's positive impact is that it can maximize existing resources and provide a quiet work environment, especially night shifts and plenty of time off. Different types of work can also cause this. According to Sunarti (2013) husband and wife work preferences affect the division of labor in the family. The study results by Carr et al. (2014) say that in husband-wife interactions, women exercise more control or provide care to partners than men. The data show that the income of health workers' families with stable working hours is higher than the shift work system. Based on Lianto \& Elizabeth (2018) research, income is closely related to financial management behavior. If a person's income is high, it will have an impact on good financial management behavior. The data show that the wife's age is more mature in the family of health workers with stable working hours than the shift work system. The mature wife's age will make the wife experience more experience and knowledge so that the implementation of family development tasks can run optimally (Tyas, Herawati, \& Sunarti, 2017). The data shows that the average length of marriage for women health workers who work with a shift system is shorter than the stable working hours, which is 5 years. Things that may cause differences in satisfaction factors associated with long marriage is according Srisusanti and Zulkaida (2013), the marriage age between 4-5 years of marriage satisfaction factor is the most dominant religious participation.

Women health workers with the shift system feel more about work-family problems, especially related to the problem of not having time for family events and getting complaints from their husbands, as well as experiencing work conflicts that disrupt family life compared to women health workers who work stable working hours. According to Gifkins, Loudoun, and Johnston (2017), the problems that arise in women health workers (nurses) when working all weekend with the shift system have the potential to rarely meet with their spouses or families. These results support those reported by Akkas, Hossain, and Rhaman (2015) in which it was found that women who are work with the shift system feel more often conflict from work that impacts family life. 
The limitation in this umbrella study is the sampling technique used in the form of nonprobability sampling (purposive sampling) so that the results of the study cannot represent the population of health workers as a whole. The subject of this research is a wife who works as a health worker, which means that it is only based on the wife's perception. In further research, it is better if the working husband is involved in the research so that it allows more complex research results, especially on different tests that can distinguish and/or compare between working wives and working husbands.

\section{Conclusion and Recommendation}

\section{Conclusion}

The regression test results in all models show that marriage satisfaction has an effect on subjective well-being. Coping strategies have a significant positive effect on subjective well-being. Work-family problems have a significant positive relationship with family work conflicts and subjective economic stress. Work-family problems and work-family conflicts have a significant negative relationship with husband-wife interactions, marital satisfaction, and subjective well-being. Time management and husband-wife interaction have a significant positive relationship. There is a significant positive relationship in husband-wife interaction and time management on marriage satisfaction, financial management, and subjective well-being. Coping strategies have a significant positive relationship with time management, marriage satisfaction, financial management, and subjective well-being. There is a significant negative relationship between subjective economic pressure and subjective well-being. Marriage satisfaction has a significant positive relationship with subjective wellbeing.

The directional dimension as a component of the husband-wife interaction of women health workers with the shift work system is higher than the stable working hours, while the dimensions of financial management and religious orientation as components of the marriage satisfaction of women health workers with stable working hours are higher than the shift work system. Women health workers with the shift system feel more about work-family problems, especially related to the problem of not having time for family events and getting complaints from their husbands, as well as experiencing work conflicts that interfere with family life compared to women health workers who work stable working hours. Women health workers with stable working hours have a higher physical-economic subjective wellbeing than women health workers with the shift system.

\section{Recommendation}

The recommendation that can be given for families, especially wives who work as health workers and have a working husband, is to be able to solve problems together, express affection, and take time to interact together, especially during the Covid-19 pandemic, so that they can maintain or increase marriage satisfaction and the subjective well-being will also increase. The family can develop various efforts as a coping strategy to overcome and balance the family's role and doing well for the work that will improve the subjective well-being of 
the family. Further researchers should explore research ideas by examining this research topic more broadly by involving husbands.

\section{References}

Achour, M., Nor, M. R. M., \& Yusoff, M. Y. Z. M. (2015). Work-family demands and subjective well-being among female academicians: The role of Muslim Religiosity. Review of Religious Research, 57(3), 419-433. Doi: https://doi.org/10.1007/S13644015-0221-6.

Aceleanu, M. I. (2012). Links between education, employment and quality of life: The case of Romania. Management \& Marketing, 7(4), 717-730.

Akkas, M. A., Hossain. M. I., \& Rhaman. S. (2015). Causes and consequences of workFamily Conflict (WFC) among the female employees in Bangladesh: An Empirical Study. Journal of Business and Economics, 12(6), 2063-2071. Doi: https://doi.org/10.15341/jbe(2155-7950)/12.06.2015/007.

Alteza, M., \& Hidayati, L. N. (2008). Work-family conflict pada wanita bekerja: Studi tentang penyebab, dampak dan strategi coping. Jurnal Universitas Negeri Yogyakarta. Retrieved from http://staff.uny.ac.id/sites/default/files/penelitian/muniya-alteza-semsi/work-family-conflict-pada-wanita-bekerjastudi-tentang-penyebab-dampak-danstrategi-coping.pdf.

Anindya, A. S., \& Soetjiningsih, C. H. (2017). Kepuasan pernikahan dengan kesejahteraan subjektif perempuan dengan profesi guru sekolah dasar. INSAN Jurnal Psikologi dan Kesehatan Mental, 2(1), 44-50. Doi: http://dx.doi.org/10.20473/jpkm.V2I12017.44-50

[BPS] Badan Pusat Statistik. (2019). Keadaan Angkatan Kerja di Indonesia Februari 2019. Jakarta (ID): BPS.

Bawono, Y. (2017). Pernikahan dan Subjective Well-being: Sebuah Kajian Meta-analisis. BIOPSIKOSOSIAL: Jurnal Ilmiah Psikologi, 1(2), 101-106. Retrieved from https://publikasi.mercubuana.ac.id/index.php/biopsikososial/issue/viewFile/243/45.

Canel, A. N. (2013). The development of the Marital Satisfaction Scale (MSS). Educational Sciences: Theory and Practice, 13(1), 97-117. Retrieved from https://eric.ed.gov/?id=EJ1016640.

Carr, D., Freedman, V. A., Cornman, J. C., \& Schwarz, N. (2014). Happy Marriage, Happy Life? Marital Quality and Subjective Well-being in Later Life. Journal of Marriage and Family, 76, 930-948. Doi: https://doi.org/10.1111/jomf.12133.

Chung, S. K. G., Chan, X. W., Lanier, P., \& Wong, P. (2020). Associations Between WorkFamily Balance, Parenting Stress, and Marital Conflicts During COVID-19 Pandemic in Singapore. Retrieved from https://scholar.googleusercontent.com/scholar?q=cache:X4_R4ZaWJZMJ:scholar.goog le.com/+family+time+management+during+covid-19+work-

family\&hl=en\&as_sdt=0,5.

Diener, E., \& Ryan, K. (2009). Subjective well-being: A general overview. South African journal of psychology, 39(4), 391-406. Doi: https://doi.org/10.1177/008124630903900402. 
Dwiyanti, R., \& Rahardjo, P. (2017). Strategi coping wanita pekerja formal dan informal dalam mengatasi konflik peran ganda di Banyumas. Indigenous: Jurnal Ilmiah Psikologi, 1(2),72-82. Doi: https://doi.org/10.23917/indigenous.v1i2.3072.

Elmanora, E., Muflikhati, I., \& Alfiasari, A. (2012). Kesejahteraan keluarga petani kayu manis. Jurnal Ilmu Keluarga \& Konsumen, 5(1), 58-66. Doi: https://doi.org/10.24156/jikk.2012.5.1.58.

Firdaus, F., \& Sunarti, E. (2009). Hubungan antara tekanan ekonomi dan mekanisme koping dengan kesejahteraan keluarga wanita pemetik teh. Jurnal Ilmu Keluarga \& Konsumen, 2(1), 21-31. Doi: https://doi.org/10.24156/jikk.2009.2.1.21.

Forsberg, L. (2009). Managing time and childcare in dual-earner families: Unforeseen consequences of household strategies. Acta Sociologica, 52(2), 162-175. Doi: https://doi.org/0.1177/0001699309104003.

Gifkins, J., Loudoun, R., \& Johnston, A. (2017). Coping strategies and social support needs of experienced and inexperienced nurses performing shiftwork. Journal of Advanced Nursing, 73(12), 3079-3089. Doi: https://doi.org/10.1111/jan.13374.

Kahneman, D., \& Deaton, A. (2010). High income improves evaluation of life but not emotional well-being. Proceedings of The National Academy of Sciences, 107(38), 16489-16493. Doi: https://doi.org/10.1073/pnas.1011492107.

Kantamneni, N. (2020). The impact of the COVID-19 pandemic on marginalized populations in the United States: A research agenda. Journal of vocational behavior, 119, 103439. Advance online publication. Doi: https://doi.org/10.1016/j.jvb.2020.103439.

[Kemenkes] Kementrian Kesehatan. (2020). Situasi Terkini Perkembangan Coronavirus Disease (COVID-19) 23 Maret 2020. Retrieved from https://covid19.kemkes.go.id/situasi-infeksi-emerging/info-corona-virus/situasi-terkiniperkembangan-coronavirus-disease-covid-19-23-maret-2020/\#.Xt71JTozbIU.

Lianto, R., \& Elizabeth, S. M. (2018). Analisis pengaruh financial attitude, financial knowledge, income terhadap financial behavior di kalangan ibu rumah tangga Palembang (Studi kasus Kecamatan Ilir Timur 1). Jurnal STIE Multi Data Palembang, 1-12. Retrieved from https://docplayer.info/88252414-Rizky-lianto-1-sri-megawatielizabeth-2-jurusan-manajemen-stie-multi-data-palembang.html.

Lu, W., Wang, H., Lin, Y., \& Li, L. (2020). Psychological status of medical workforce during the COVID-19 pandemic: A cross-sectional study. Psychiatry Research, 288, 112936. Doi: https://doi.org/10.1016/j.psychres.2020.112936.

Marchelia, V. (2014). Stres kerja ditinjau dari shift kerja pada karyawan. Jurnal Ilmiah Psikologi Terapan, 2(1), 130-143. doi: https://doi.org/10.22219/jipt.v2i1.1775.

Meliani, F., Sunarti, E., \& Krisnatuti, D. (2014). Faktor demografi, konflik kerja-keluarga, dan kepuasan pernikahan istri bekerja. Jurnal Ilmu Keluarga \& Konsumen, 7(3), 133142. Doi: http://dx.doi.org/10.24156/jikk.2014.7.3.133.

Minnotte, K. L., Minnotte, M. C., \& Bonstrom, J. (2015). Work-family conflicts and marital satisfaction among US workers: Does stress amplification matter? Journal of Family and Economic Issues, 36(1), 21-33. Doi: http://dx.doi.org/10.1007/s10834-014-9420-5.

[OECD] Organization for Economic Co-operation and Development. (2013). OECD guidelines on measuring subjective well-being. Paris: OECD Publishing. 
Prime, H., Wade, M., \& Browne, D. T. (2020). Risk and resilience in family well-being during the COVID-19 pandemic. American Psychologist, 75(5), 631-643. Doi: http://dx.doi.org/10.1037/amp0000660.

Rizkillah, R., Sunarti, E., \& Herawati, T. (2015). Kualitas perkawinan dan lingkungan pengasuhan pada keluarga dengan suami istri bekerja. Jurnal Ilmu Keluarga \& Konsumen, 8(1), 10-19. Doi: https://doi.org/10.24156/jikk.2015.8.1.10.

Ryu, G. W., Yang, Y. S., \& Choi, M. (2020). Mediating role of coping style on the relationship between job stress and subjective well-being among Korean police officers. BMC Public Health, 20(1), 1-8. Doi: https://doi.org/10.1186/s12889-020-08546-3.

Srisusanti, S., \& Zulkaida, A. (2013). Studi deskriptif mengenai faktor-faktor yang mempengaruhi kepuasan pernikahan pada istri. UG Journal, 7(6), 8-12. Retrieved from https://ejournal.gunadarma.ac.id/index.php/ugjournal/article/view/1198.

Steen, A., \& MacKenzie, D. (2013). Financial stress, financial literacy, counselling and the risk of homelessness. Australasian Accounting, Business and Finance Journal, 7(3), 3148. Doi: https://doi.org/10.14453/aabfj.v7i3.3.

Sun, X., McHale, S. M., Crouter, A. C., \& Jones, D. E. (2017). Longitudinal links between work experiences and marital satisfaction in african american dual-earner couples. Journal of Family Psychology,31(8), 1029-1039. Doi: https://doi.org/10.1037/fam0000381.

Sunarti, E. (2001). Studi ketahanan keluarga dan ukurannya: telaah kasus pengaruhnya terhadap kualitas kehamilan [Disertation]. Bogor: Institut Pertanian Bogor.

Sunarti, E. (2013). Ketahanan Keluarga (Penjelasan Materi Family Kit). Bogor (ID): IPB Press.

Sunarti, E. (2020). Survey ketahanan keluarga di masa pandemi Covid-19. Dipresentasikan pada seminar online Science-Policy Interface The 14th IPB Strategic Talk Covid-19, Bogor, Indonesia.

Suwartini, S., \& Casmini, C. (2019). Subjective well-being dalam perspektif istri berjauhan dengan suami. Marwah: Jurnal Perempuan, Agama dan Jender, 18(1), 67-86. Retrieved from http://ejournal.uin-suska.ac.id/index.php/marwah/article/view/6451.

Sunarti, E., Rizkillah, R., \& Muktiyah, N. T. (2020). The Effect of Work-Family Conflict and Balancing Strategy towards Wive's Job Satisfaction. Journal of Family Sciences, 5(1), 20-35. https://doi.org/10.29244/jfs.5.1.20-35.

Tyas, F. P. S., Herawati, T., \& Sunarti, E. (2017). Tugas perkembangan keluarga dan kepuasan pernikahan pada pasangan menikah muda. Jurnal Ilmu Keluarga dan Konsumen, 10(2), 83-94. Doi: http://dx.doi.org/10.24156/jikk.2017.10.2.83.

[WHO] World Health Organization. (2019). Gender Equity in The Health workforce: Analysis of 104 country (no. WHO/HIS/HWF/Gender/WP1/2019.1). World Health Organization.

Yang, N., Chen, C. C., Choi, J., \& Zou, Y. (2000). Sources of work-family conflict: A SinoU.S. comparison of the effects of work and family demands. The Academy of Management Journal, 43(1), 113-123. Doi: https://doi.org/10.2307/1556390. 